entirely post-Silurian. As mentioned above, the Palaeozoic succession of the southeastern part of peninsular Thailand comprises Lower Palaeozoic rocks of quite different facies from the Phuket Group: deltaic deposits (Jones, 1968) overlain by the Thung Song Limestone. And yet the succeeding group of Middle Devonian (Kobayashi \& Hamada, 1968) to Permo-Carboniferous age has lithological similarities with the Phuket Group and is most simply viewed as being its lateral equivalent. Furthermore, the numerous limestone clasts in the Phuket Group tilloids are lithologically like the Ordovician to Silurian Thung Song Limestone and if they were derived from the latter (or its equivalent to the west?) the Phuket Group must be younger.

Acknowledgement. I am indebted to The British Petroleum Company Limited for permission to publish this note.

\title{
References
}

Biswas, B. 1970. Rising continents, deepening ocean basins and their changing configuration. Basudeb Biswas, Calcutta.

Garson, M. S. \& Mitchell, A. H. G. 1970. Transform faulting in the Thai Peninsula. Nature, Lond. 22, 45-7.

Jones, C. R. 1968. Lower Paleozoic rocks of the Malay Peninsula. Bull. Am. Ass. Petrol. Geol. 52, 1259-78.

Kobayashi, T. \& Hamada, T. 1968. A Devonian phacopid recently discovered by Mr Charan Poothai in peninsular Thailand. In Kobayashi, T. and Toriyama, R. (Eds.): Geology and palaeontology of Southeast Asia, Vol. 4, 22-8. University of Tokyo Press, Tokyo.

Mitchell, A. H. G., Young, B. \& Jantaranipa, W. 1970. The Phuket Group, Peninsular Thailand: a Palaeozoic ?geosynclinal deposit. Geol. Mag. 107, 411-28.

Schermerhorn, L. J. G. \& Stanton, W. I. 1963. Tilloids in the West Congo geosyncline. Q. Il geol. Soc. Lond. 119, 201-41.

BP Petroleum Development Ltd

Box 2814

Singapore

1st April 1971

\section{The Phuket Group of Peninsular Thailand}

SIR,-We are grateful to Mr Ridd for showing that to the south and east of the Klong Marui fault the Phuket Group lies unconformably on the Thung Song Limestone. Ridd's results indicate that here, at least, the base of the Phuket Group is no older than late Silurian.

Within Peninsular Thailand conclusive evidence for the direction of provenance of the Phuket Group is so far lacking. Although sedimentary facies and vertical facies relationships can be recognised, lack of detailed stratigraphic control in a folded and faulted succession obscures lateral facies relationships; comparison of lithologies in widely separated exposures of limited area is of doubtful value as a basis for paleogeographic reconstructions. The predominantly argillaceous succession described by Ridd from the area to the south-east of the Klong Marui Fault may be a distal deep water deposit; alternatively it could be interpreted as having accumulated in a restricted environment near an easterly source area, while thicker flysch-type sediments were deposited in deeper water further west.

The paired eugeosynclinal and miogeosynclinal belts of the Malay Peninsula (Jones, 1968) have a northerly trend and lie well to the south-east of Peninsular Thailand. The belts are of Lower Palaeozoic age and hence older than much and possibly all of the Phuket Group. Ridd suggested that limestone pebbles in the Phuket Group were derived 
from the Thung Song Limestone, which they resemble lithologically and which lies unconformably beneath the Group in the east of the Thai Peninsula. It could be argued that the terrigeneous detritus in the Phuket Group was derived from rocks beneath and to the east of the Thung Song Limestone, representing the northward extension of the Lower Palaeozoic geosynclinal rocks now exposed in the Malay Peninsula. However, until more conclusive evidence is found, the direction of provenance will remain in doubt. On broad regional grounds we see no reason to dismiss the ideas of earlier Dutch workers that the source lay to the east, rather than to the west as has been suggested by Jones (1968), Burton (1970) and Ridd.

\section{References}

Burton, C. K. 1970. The Palaeotectonic status of the Malay Peninsula. Palaeogeography, Palaeoclimatol., Palaeoecol. 7, 51-60.

Jones, C. R. 1968. Lower Palaeozoic rocks of Malay Peninsula. Bull. Am. Ass. Petrol. Geol. 52, 1259-78.

A. H. G. MITCHELL,

Dept. of Geology and Mineralogy

Parks Road, Oxford

B. YOUNG,

Institute of Geological Sciences,

5 Princes Gate, London, S.W.7.

10th June 1971
W. JANTARANIPA,

Dept of Geology

University of Strathclyde

George Street, Glasgow, C.1.

\section{Tectonic ripples and associated minor structures in the Silurian rocks of Denbighshire}

SIR,-Warren, Harrison, Wilson, Smith \& Nutt (1970) are mistaken in supposing that theirs is the first reference to the combination of lineation, small folds (ripples) and thin calcite-quartz sheets from the Silurian of Denbighshire. There is a considerably earlier account of an identical association in the Geological Survey memoir of the Wrexham district in which the Silurian rocks of the Llangollen Synclinorium are described (Wedd, Smith \& Wills, 1927, p. 91). In addition there is later work by Nettle (1964) and myself (Nicholson, 1966) also from Llangollen. The mullions of Warren et al. (1970), however, do not seem to have been described before.

Both Nettle (1964, p. 223) and Warren et al. (1970, p. 59) have proposed that the small folds they describe are later than the cleavage and larger folds of the rocks that contain them and require for their formation some special deformation at their own level not found generally in the region. I think rather that the two are expressions of the same deformation; buckling, often with flexural slip, being restricted to horizons at which the relatively stiff but often foliated calcite-quartz sheets occur, such deformation changing quickly into layer-parallel shortening in the mudstone and shale beyond (Nicholson, 1964, 1966, pp. 120-4). Broadly this also was the early survey view (Wedd et al., 1927).

In some ways the evidence in the Llangollen area is better developed to support an argument that the fold and cleavage structures belong together than the area to its north in which Warren et al. have worked. Thus I give an outline of the Llangollen argument below. Before I do so, however, there is one objection which might be made by Warren et al. to the proposition made above. This objection is that most of their small folds appear to occur at levels at which no calcite-quartz layers are known so that buckling, etc., as described above could not occur. However, at Llangollen it is clear that no calcite-quartz sheet reaches ground surface; traced upwards in a quarry the sheets are increasingly weathered towards it and as far as I am aware there is no positive evidence 